\title{
ON VAN DE LUNE - ALZER'S INEQUALITY
}

\author{
S. Abramovich, J. BARIĆ, M. MATIĆ AND J. PEČARIĆ
}

Abstract. In this paper it is shown that the inequality known in the literature as Alzer's inequality (1993), has already been known since 1975. and is due to Jan van de Lune. A review of different methods in proving Van de Lune - Alzer's inequality and generalizations in a several directions, is given. It is shown how some results and proofs can be corrected, refined and extended. New results, inspired by the generalization of Van de Lune - Alzer's inequality for increasing convex sequences presented by N. Elezović and J. Pečarić, are obtained.

Mathematics subject classification (2000): 26A51, 26D15, 26 D20.

Key words and phrases: sequences, convex functions, inequalities.

\section{REFERENCES}

1] Nieuw Archief Voor Wiskunde, 3rd series, XXIII, no. 3, November 1975, pp. 254-257.

[2] H. Alzer, On an inequality of H. Minc and L. Sathre, J. Math. Anal. Appl. 179 (1993), 396-402.

[3] H. AlZER, Refinement of an inequality of G. Bennett, Discrete Math. 135 (1994), no. 1-3, 39-46.

[4] G. Bennett, G. Jameson, Monotonic averages of convex functions, J. Math. Anal. Appl. 252 (2000), 410-430.

[5] I. BRnetić, J. PeČArić, Comments on some analytic inequalities, J. Inequal. Pure Appl. Math. 4, (2003), no. 1 , Article 20.

[6] C.-P. CHEN, F. QI, Notes on proofs of Alzer's inequality, Octogon Mathematical Magazine 11 (2003), no. $1,29-33$.

[7] C.-P. CHEN, F. QI, The inequality of Alzer for negative powers, Octogon Mathematical Magazine 11 (2003), no. 2, 442-445.

[8] C.-P. CHEN, F. QI, On integral version of Alzer's inequality and Martins' inequality, RGMIA Research Report Collection 8 (2005), no. 1, Article 13. http://rgmia.vu.edu.au/v8n1.html.

[9] C.-P. CHEN, F. QI, Monotonicity properties for generalized logarithmic means, Australian Journal of Mathematical analysis and Applications 1, (2004), no. 2, Article 2.

[10] C.-P. CHEN, F. QI, Extension of an inequality of H. Alzer for negative powers, Tamkang J. Math. 36 (2005), no. 1, 69-72.

[11] C.-P. CHEN, F. QI, Generalization of an inequality of Alzer for negative powers, Tamkang J. Math. 36 (2005), no. 3, 219-222.

[12] C.-P. CHEN, F. QI, Note on Alzer,s inequality, Tamkang J. Math. 37 (2006), no. 1, 11-14.

[13] C.-P. ChEN, F. QI, P. CERONE, S.S. DRAGOMIR, Monotonicity of sequences involving convex and concave functions, Mathematical Inequalities and Applications 6 (2003), no. 2, 229-239.

[14] S.S. DRAGOMIR, J. VAN DER HOEK, Some new inequalities and their applications in guessing theory, J. Math. Anal. Appl., 225 (1998), 542-556.

[15] S.S. DRAGOMIR, J. VAN DER HOEK, Some new inequalities for the average number of guesses, Kyungpook Math. J., 39, (1999.), no. 1, 11-17.

[16] N. Elezović, J. PeČARIĆ, On Alzer's inequality, J. Math. Anal. Appl. 223 (1998), 366-369.

[17] I. GAVREA, Operators of Bernstein-Stancu type and the monotonicity of some sequences involving convex functions, Conference on Inequalities and Applications '07, preprint.

[18] B. Gavrea, I. GavreA, An inequality for linear positive functionals, J. Inequal. Pure Appl. Math. 1 (2000), no. 1, Article 5. 
[19] B.-N. Guo, F. QI, Inequalities and monotonicity of the ratio for the geometric means of a positive arithmetic sequence with arbitrary difference, Tamkang J. Math. 34 (2003), no. 3, 261-270.

[20] J.-C. KuAng, Some extensions and refinements of Minc-Sathre inequality, Math. Gaz. 83 (1999), $123-127$

[21] A.-J. LI, X.-M. WANG AND C.-P. Chen, Generalizations of the Ky Fan inequality, J. Inequal. Pure Appl. Math. 7 (2006), no. 4, article 130.

[22] A.W. Marshall, I. OlKin, F. PROSCHAN, Monotonicity of ratios of means and other applications of majorization. in Inequalities, O. Shisha (ed.), New York-London (1967), 177-190.

[23] J.S. MARTINS, Arithmetic and geometric means, an applications to Lorentz sequence spaces, Math Nachr. 139 (1988), 281-288.

[24] H. Minc, L. SATHRE, Some inequalities involving $(r !)^{\frac{1}{r}}$, Proc. Edinburgh Math. Soc. $14(1964 / 65)$, $41-46$.

[25] C.E.M. PeARCE, J.E. PeČARIĆ, On the ratio of logarithmic means., Anzeiger. Oester. Akad. Wiss. Math.Naturwiss. Klasse. 131 (1994), 39-44.

[26] F. QI, Generalization of H. Alzer's inequality, J. Math. Anal. Appl. 240 (1999), no. 1, 294-297.

[27] F. QI, Generalizations of Alzer's and Kuang's inequality, Tamkang Journal of Mathematics 31 (2000), no. 3, 223-227.

[28] F. QI, An algebraic inequality, J. Inequal. Pure Appl. Math. 2, (2001), no. 1, Article 13.

[29] F. QI, L. DEBNATH, On a new generalization of Alzer's inequality, International Journal of Mathematics and Mathematical Sciences 23 (2000), no. 12, 815-818.

[30] F. QI, B.-N. GUO, Monotonicity of sequences involving convex function and sequence, Math. Inequal. Appl. 9 (2006), no. 2, 247-254.

[31] F. QI, B.-N. GuO, L. DeBnATH, A lower bound for ratio of power means, International Journal of Mathematics and Mathematical Sciences - Vol. 2004, no. 1, 49-53.

[32] F. QI, Q.-M. LUO, Generalization of H. Minc and Sathre's inequality, Tamkang J. Math. 31 (2000), no. $2,145-148$.

[33] J. SÁNDOR, On an inequality of Alzer, J. Math. Anal. Appl. 192(1995), 1034-1035.

[34] J. SÁNDOR, On an inequality of Alzer, II, O. Math. Mag. 11(2003), no. 2, 554-555.

[35] J. SÁNDOR, Comments on an inequality for the sum of powers of positive integers, RGMIA Research Report Collection 2 (1999), no. 2.

[36] J. SÁNDOR, On an inequality of Bennett, General Mathematics (Sibiu) 3 (1995), no. 3-4, 121-125.

[37] J. SÁNDOR, On an inequality of Alzer for negative powers, RGMIA Research Report Collection 9 (2006), no. 4.

[38] J.S. UME, An elementary proof of H. Alzer's inequality, Math. Japon. 44 (1996), no. 3, 521-522.

[39] J.S. UME, An inequality for a positive real function, Math. Inequal. Appl. 5 (2002), no. 4, 693-696.

[40] Z. XU, D. XU, A general form of Alzer's inequality, Computers and Mathematics with Applications 44 (2002), 365-373.

[41] S.-L. ZhAng, C.-P. Chen, F. QI, Continuous analogue of Alzer's inequality, Tamkang J. Math. 37 (2006), no. 2, 105-108. 